\title{
Gandhian Perspectives and Alternative Development: How Third World Influenced Development Thinking?
}

\author{
Ratna Mani Nepal
}

\begin{abstract}
Alternative development thinking emerged in the decade of seventies. This tradition in development studies was partially influenced by the ecological movements in the west. In majority, however, the trend referred to the critical voices in the Third World. In its movements associated with colonialism and domestic feudalism, Third World raised issues which rejected the mainstream development pedagogy. Gandhi of India and Mao Tse Zung of China were among them who opposed western hegemony and practiced alternative traditions. Buddhist economics too is supposed to an alternative economics. This article discusses Mahatma Gandhi's development perspectives in order to examine them in pursuit of alternative development of the seventies. The main objective of the study is to analyze Gandhian principles of social and economic transformation from alternative development perspectives. Required information has been accessed from published library and online sources e.g. books, journals, reports etc. Narrative analysis technique is applied to examine the obtained information. This study concludes that concepts like self-reliance, appropriate technology, critic to capitalism, sustainability, and freedom as discussed in alternative development thinking in the seventies seem to be influenced by Gandhian development perspectives.
\end{abstract}

Index Terms - Alternative Development; Gandhi, Freedom, Non-violence, Self-reliance, Trusteeship.

\section{INTRODUCTION}

Studies argue that alternative development discourse of the seventies received influence from the ideas that opposed mainstream paradigm, basically the modernity (Nederveen Pieterse, 2010, p. 86). These opposition voices in general criticized colonialism, capitalism, and their associated explanations. Despite the fact that these ideas materialized in western tradition, the trend received moral support from the third world movements and critical positions there. The principles as discussed in Gandhism, Maoism, Buddhist economics (Ibid.) and Non-alignment movement (NAM-1956) are a few examples. What alternative explanations did these ideological and historical accounts in the Third World had? In this study, ideas of India's Mohandas Karamchand Gandhi (MK Gandhi, 1869-1948) are analyzed if they complement alternative development thinking.

Mahatma Gandhi, as he is popularly known as, is a towering figure of India's independence movement. He is well known for his non-violent form of resistance against colonialism. Moreover, his ideas of self-reliance and rural

Dr. Ratna Mani Nepal is Lecturer at Central Department of Rural Development, Tribhuvan University, Kathmandu. development, explained as village swaraj, have gotten space in development studies (Rist, 2009; Cowen \& Shenton, 1996; Hettne, 1987). In general, Gandhi's ideals were against western civilization. He criticized mainstream economics and proposed an alternative moral economics (Namita, 2017) based on local resources of all sorts. His development thinking represents case of a developing country in the context of ongoing anti-colonial movement. What alternative thinking had he to offer the field of development? In fact, was Gandhian thinking alternative or conservative if compared with the contemporary discourses?

This article discusses Gandhian development thinking and examines if it complements the principles of alternative development. This study employs narrative analysis method to discuss Gandhian perspectives. For the purpose of analysis, published sources such as books, journals, periodicals, online archives are accessed.

\section{BRIEF REVIEW OF ALTERNATIVE DEVELOPMENT}

In the seventies, world's economy was put under severe critic for its inability to reduce division and poverty among the people and the states. Anxiety was expressed against capitalist economy propagated by modernization theory. It was visible in 'The Limits to Growth, 1972' by Club of Rome. The environmental concern was expressed metaphorically by Rachael Carson in 'The Silent Spring 1962', also in the 'Blueprint for Survival (1973) by The Ecologist. The post-war development notion that 'painful readjustments' was needed in specialized, efficient, productive, achievement-oriented social, political, and cultural structures was challenged by 'movement politics' around the globe. Friedman (1992) notes some of the movements including America's Women movement, Cultural Revolution in China, Africa's Black Power Movement, and Paris Student Uprising. In this list, Saemaul Undong movement in South Korea, social movements in Latin America and movements in South Asia e.g. Naxalites in India and Nepal, lingual movement in Bangladesh are worth to add.

According to Bidwai (n.d.), the social movements of the era were the symptom of the vulnerability of the Golden Age of Capitalism, which began with the end of World War II and expanded in the developing countries through modernization. To Pieterse (2010), the dissatisfaction was with mainstream development.

The discontents gradually entered the intellectual discourses. The scholars from around the world, supposed to be socialist in orientation, converged in forums and expressed 
concern for alternative development, particularly in the third world. In 1972, Stockholm Conference on the Human Environment was held; in 1974, Cocoyoc Seminar on 'Patterns of Resource Use, Environment, and Development Strategies' was organized. In these forums, issues discussed were economic growth, development strategies, and conditions of ecology, and population, concern for people-centered development among others (Friedman, 1992, p. 2).

The issues were also recognized by the United Nations, established in 1945 to coordinate programs of development, cooperation, and peace at the global level. On a number of occasions, United Nations revised its former development policies and strategies given the new concerns of growing economic inequalities, social and cultural injustice, and environmental degradation. One of such turns was its decision taken during Sixth Special Session of General Assembly (1974) to establish New International Economic Order (NIEO). In a study, Mahiou (2011) examines that 'the new international economic order testifies first and foremost to the determination of the new states that emerged from decolonization to participate effectively in international life and, if not to discredit, at least to radically overhaul the global economic system put in place in the aftermath of the Second World War. They believed that such as system (represented by the International Monetary Fund, the World Bank, and the General Agreement on Tariffs and Trade (GATT)), based on liberal principles, and completely dominated by a few Western powers led by the United States, no longer met contemporary needs'.

Given all the discussion on the rise of alternative development, Third World's tradition is simply unseen and underrated. Despite the fact that Third World leaders and movements expressed their dissatisfaction of the use of high-Tec, economy and its impacts on the society and economy, studies on alternative development development often neglect these accounts in to discussion. In this study, Gandhian thoughts are analyzed and juxtaposed if they have some level of significance as alternative development tradition.

\section{DISCUSSION}

\section{A. Gandhi's Development Perspectives: The Context}

Gandhi's period began with the twentieth century until its middle. It was fully a period of decolonization movement, of which Gandhi played a key leadership. Therefore, a study on Gandhian perspectives of development needs to be contextual examining the contexts of India's politics, economy, and society of the period. Nevertheless, Gandhi had an exposure to European modernity while he was a lawyer in South Africa. There he experienced unequal treatment by British folks in his individual as well as the professional carrier. Parekh (1997) mentioned that Gandhi's world-view took a preliminary shape in Europe, which he elaborated and organized latter back during the Independence Movement in India.

In the first half of twentieth century India, British colonial rule was firmly instituted. The rule by foreigners affected freedom and justice of the local people. It was, indeed, a centralized system consolidated under the British colony the various indigenous kingdoms in the regions. Consequently, the local political tradition based on Panchayat could be weak or disappear. It could further exploit people of their dependency and increasing expenses for any political transactions. Economically, a town-village dichotomy was evolving given the concentration of industries, railways, and administrative services in some areas. The towns were served by foreign education and hospitals. To the contrary, the villages were the units of subsistence agriculture run by tenant farmers in the majority. The landlords were closer to the British colonial officers in many instances. Traditional practices of education, health, and farming served the village inhabitants. Rich in social and culturally diverse resources, the Indian villages were millions in number scattered throughout the regions.

And, Gandhi was firmly convinced that India's independence could not be won by modern weapon but by the mobilization of the millions of farmers living in the villages. The imperial British power was itself equipped with modern arms; Gandhi had to fight with an alternative. It was a big political economic challenge before him. Therefore, Gandhian principles of development took shape in these contexts as counter-hegemony to Western modernity, which was entered India and destroyed its tradition in many spheres. The modernity, according to Parekh (1997) had various forms such as 'urbanization, industrialization, rationalization, secularization, technological mastery over nature, the drive towards globalization and liberal democracy'. Gandhi devised a model of change contrary to these values, which he thought were pernicious to Indian's freedom.

\section{B. Self-reliance}

Gandhi imagined completely self-reliant model village, an alternative to the cities. He viewed it as a unit having all the features contrary to the Western modernity. The village was a symbol of freedom, non-violence, and sufficiency in all other domains including technology to meet the material needs and non-material necessities of its members. On the political and economic periphery of the village, a Gandhian model of development is based on.

Following words which Gandhi delivered in the early twenties represent Gandhi's motives behind the formulation of development. In Young India (1926), he said: “...to make India like England and America is to find some other races and places of the earth for exploitation...the fact is that this industrial civilisation is a disease because it is all evil. Let us not be deceived by catchwords and phrases..." (In Numita, 2014). Furthermore, he remarked:

"Neither railways nor hospital is a test of a high or pure civilisation. At best they are a necessary evil. Neither adds one inch to the moral stature of a nation. Nor am I aiming at a permanent destruction of law courts, much as I regard it as a 'consummation devoutly to be wished.' Still less I am trying to destroy all machinery and mills. It requires a higher simplicity and renunciation than the people are today prepared for".

Parekh (2014) discussed that Gandhi learned Western civilization and its impact while he was practicing law in South Africa during the first decade of the twentieth century. 
Besides, he was truly influenced by the ideas of Tolstoy, Pushkin and Rossouw. Nevertheless, British colonialism in India was also the learning center of modernity to him. Gandhi himself admitted that his experience of Indian citizens and society was advanced during the long Harijan tour across the country.

An alternative to the Western civilization and its penetrating evils and violence in Indian pocket cities, Gandhi envisaged village swaraj. The village swaraj was a complete republic, freed even from its neighbors for its actual needs, but interdependent for many other essential needs. The Swaraj was based on the principles of self-reliance, Sarvodaya, and non-violence.

In the independent village, people's real needs are met locally. Everyone work for all and all was responsible for each. Individuals subscribed to the society for their wants, and society acted for the individual. It was a society where all members of the society could be fairly served to get better well fare as well as well-being. The service could not come from external sources, though. The self-reliant villages could themselves generate whatever and how much they required. The village could develop its own system of governance, economy, and institutions of production and distribution.

Politically, the village swaraj would be governed by Panchayat, 'an assembly of five elected by villagers'. The Panchayat was a combination of executive, legislature, and judiciary. Gandhi believed that India had a good tradition of this ancient republic governing millions of villages before they were destroyed by the British rule. Now, their returned was possible as village swaraj. The society could run with moral authority, strict impartiality and the willing obedience of the parties concerned. It was a fully independent republic exercising self-government in every affair. It could guarantee education, sanitation, health and sanitation, and justice to the untouchables. It ensured capable and self-sustained management. Everyone in the society knew his or her wants as well as their limitations. Such a society was a central unit of any true democracy, where the individual was the unit of non-pyramidal social circles in millions. He said:

In this structure composed of innumerable villages, there will be ever widening, never ascending circles. Life will not be a pyramid with the apex sustained by the bottom. But it will be an oceanic circle whose centre will be the individual always ready to perish for the village, the latter ready to perish for the circle of villages, till at last the whole becomes one life composed of individuals, never aggressive in their arrogance but ever humble, sharing the majesty of the oceanic circle of which they are integral units (Gandhi, 1952, p. 58).

The villages Gandhi postulated were based on horizontal social and economic relationships, alternative to vertical and pyramidal structures of modern societies. There was no competition and wealth accumulation among the members. It was a balanced and harmonious society.

Under Swaraj based on non -violence nobody is anybody's enemy, everybody contributes his or her due quota to the common goal, all can read and write, and their knowledge keeps growing from day to day. Sickness and disease are reduced to the minimum. No one is a pauper and labor can always find employment (Gandhi in Namita, 2014).

\section{Non-violence: Means of social and economic justice}

Principles of non-violence were the fundamental ideology evoked by Gandhi. They were binding to the operation of village swaraj in all respect. He devised non-violence in counter to the Western civilization. The exploitation, disrespect, inequality, individualism, alienation, materialism among others were all violence, according to Gandhi. These various forms of violence are the product of modernity, especially the Western modernity. What is non-violence then? Truth, love, respect, obedience, interdependence between man and nature, trusteeship, and self-realization were the non-violence. The village swaraj could depend on them.

Gandhi believed that absolute non-violence was impossible on the earth. He said 'since all activity involves some measure of violence, all we have to do is to minimize the violence involved in it' (Gandhi, 1952, p. 46). According to him, agriculture was such an occupation, which involved less degree of it. Moreover, it was also a matter of possession, motive, use of labor, technology while doing the occupation by someone. Gandhi said:

'For when a man is content to own only so much land as he can till with his own labor, he cannot exploit others. Handicrafts exclude exploitation and slavery. Large-scale machinery concentrates wealth in the hands of one man who lord it over the rest who slave for him (Gandhi, 1952, p. 47).

According to Bharatan Kumarappa, one of his followers, Gandhi's economy based on agriculture was the non-violent economy. It was composed of occupations that involve the least possible violence, no exploitation, or envy of others, organized not based on the rights of man but on the duties of man. The labor got payment in kind, not in cash. The economy applied no large-scale machinery. It was based on the body labor. These were the appropriate technologies, which could use people's labor and create a non-violent condition. The technologies were locally tailored, maintained, met local needs, and social and cultural in character. The spinning wheel was a model example. Gandhi believed that the non-violent economy could thus be owned by the masses. The masses could involve in production and distribution opposition to the pattern in mainstream economy owned by few and distributed to many.

\section{Trusteeship: Means of equality}

Gandhian model of distribution was based on moral values as well as some local institutions. Trusteeship was such a value that he explained could bring equality of wealth in society. He thought that the wealthy people possess not a rupee more than their neighbors could. It was their self-denial to accumulate wealth at the expense of poor fellows. Gandhi remarked:

The rich man will be left in possession of his wealth, of which he will use what he reasonably requires for his personal needs and will act as a trustee for the remainder to be used for the society. In this argument, honesty on the part of the trustee is assumed (Gandhi, 1952, p. 43).

It was non-violence and honest act of self-restraint by the wealthy people. Gandhi believed it was possible because those people were the servant of the Swaraj and vice versa. He also remarked an option that if that did not happen, poor 
and deprived needed to take part in non-violence and non-cooperation act to make the wealthier trustees. Cooperatives were the next institutions that could play as distributing channel in villages. For Gandhi, they were suited for developing village industries as well as promoting group efforts to achieve common goals of Swaraj.

Gandhi's concept of trusteeship was a non-materialist formulation alternative to materialism espoused by the modern economy. As such, the non-violence economy itself meant non-materialism where the system could meet people's actual needs. People had to restraint other needs because resources were finite to meet the ever-increasing needs, which Gandhi called greed. He believed that nature could meet people actual needs, but not the greed. It was a dematerialized production and consumption cycle that people could control on their own needs, not the needs controlled their material want.

\section{E. Charkha: A symbol of freedom}

In a number of contexts, Gandhi formulated counter arguments that summon his fellow citizens to participate in the independence movement, have a legacy of Indian tradition, and stand opposite to modern foundations. For example, Why Gandhi emphasized charkha as an enabler and a means of people's freedom. The answer is that it was Gandhi's claim over the leadership, not just for the independence movement but also for future India. The emphasis in charkha was his trust on the power of his fellow comrades. He could believe that given the growing population and needs of the Indian people, the low scale traditional technology could serve less than any new technologies that he knew. However, a challenge to the British Raj could have been possible only when there had some alternative means claimed to be local, known to the public, and applicable.

\section{F. Rejection of money and independence}

Gandhi rejected the role of the money in making village swaraj a model. His denial of money for development work was the money given by Westerns such as American and British. However, he could accept Engineers if the countries could send to share scientific knowledge to the Indian folks. He believed that money could do more harm than good. It was his reaction to the negative implications of the colonial projects such as industrialization, infrastructure, and plantation in the Indian societies. With the denial of money, Gandhi could formulate a new anti-colonial weapon, which was common to the poor Indian farmers living in the villages. It could transfer power from the few wealthy and colonialist to the millions of farmers.

\section{CONCLUSION}

Overall, it can be concluded that Gandhian way of thinking development was a result of counter-hegemony shaped in different political and economic contexts. The contexts were the learning units; the counter-hegemony was the conceptual weapon. As such, it aimed self-reliant villages, the village swaraj, capable enough to support the independence movement. Gandhi wanted to react colonialism through Indian tradition. This strategy has been interpreted as a populist strategy (Rist, 2008). In the words of Hettne (1976),
'Gandhi is probably the most populist thinker in the Third World'. Nevertheless, the tradition of development thinking shows that it carries specific traditions and builds on propositions of political and economic programs evolved in contexts.

Gandhi's development perspectives implied completely autonomous self-reliance villages. He denied capital, high technology, and modern knowledge arguing that they belong to the west. Gandhi's perspectives represented India during the anti-colonial movement.

If ideas of Gandhi are taken into account, alternative development tends to be embedded in decolonization process. Their account of big technologies, capitalism, accumulation of capital, distribution, equality, and justice, freedom and sustainability precisely explains alternative development of the seventies. These came up in discourse of counter hegemonic critique of colonialism, which Gandhi raised and practiced during the de-colonization movement.

\section{REFERENCES}

[1] Acharya, N. (Ed.). (2001). BP Koirala: Nepali congresska char aashak (In Nepali). Kathmandu: Sambatsar.

[2] Alatas, S. F. (2006). Alternative discourses in Asian social sciences; Responses to Eurocentrism. New Delhi: Sage Publications.

[3] Bidwai, P. (n.d). From what now to what next: Reflections on three decades of international politics and development. Retrieved from, https://www.tni.org/files/whatnext.pdf. (accessed on 27/5/2018).

[4] Chatterji, B. (1977). Nepal's experiment with democracy. New Delhi: Ankur Publishing House.

[5] Escobar, A. (1995). Encountering development: The making and unmaking of the third world. NJ: Princeton University Press.

[6] Esteva, G. (2000). Development. In W. Sachs (Ed.), The development dictionary: A guide to knowledge to power, (pp. 9-18). New Delhi: Orient Longman.

[7] Friedmann, J. (1992). Empowerment: The politics of alternative development. Oxford: Blackwell.

[8] Gandhi, M. K. (1952). Rebuilding our villages. Konark: Nawajeevan Publishing Houses.

[9] Koirala, B.P. (2014). Democracy indispensable for development (2nd ed). Kathmandu: BP Museum.

[10] Mahiou, A. (2011). Declaration on the establishment of a new international economic order. New York: United Nations. Retrieved from, www.un.org/law/avl. (accessed 28/3/2018).

[11] Namita, (2014). Gandhi's vision of development: Relevance for 21st century. Indian Journal of Public Administration, 128, 59 (1). Retrieved from, www.iipa.org.in/New\%20Folder/9-Nuti.pdf. (accessed on 11/4/2017)

[12] Parekh, B. (1997). Gandhi (e-book). Retrieved from, https://books.google.com.np/books/about/Gandhi.html? (accessed on 10/5/2017).

[13] Peet, R., \& Hartwick, E. (2010). Theories of development: Contentions, argument, alternatives (2nd ed.). Jaipur: Rawat Publications.

[14] Pieterse, J.N. (2010). Development theory. New Delhi: Sage.

[15] Preston, P. W. (1987). Rethinking development: Essays on development and Southeast Asia. London and New York: Rutledge and Kegan Paul.

[16] Rist, G. (2008). The history of development: From western origins to global faith. London: Zed books. 